\title{
Os lazaristas e a política imperial - a escola, a assistência e a família
}

Jefferson de Almeida Pinto*

\section{RESUMO}

Este artigo propóe uma discussão sobre a dinâmica política que estava por trás da expansão lazarista nas instituiçóes escolares e assistenciais e as limitaçôes impostas pelo campo político imperial ao clero ultramontano. Trabalhamos com a hipótese de que tanto a expansão como a necessidade de controle eram formas de manter o domínio sobre a família, algo que, entendemos, era disputado pela Igreja e pelo Estado. Discutimos também um conceito de "questão religiosa" no Brasil do século XIX.

Palavras-chave: regalismo; ultramontanismo; circulação de ideias; questão religiosa; reforma da Igreja.

\section{ABSTRACT}

This paper proposes a discussion on the political dynamics behind the Lazarist expansion toward schools and welfare institutions, and the limitations imposed by the Empire's political field to the ultramontane clergy. We worked with the hypothesis that both the expansion and the need for control were means of dominating over the family, which, from our point of view, was disputed by the Church and the State. We have also discussed a concept of "religious issue" in nineteen-century Brazil.

Keywords: regalism; ultramontanism; circulation of ideas; religious issue; Reform.

DOI - http://dx.doi.org/10.1590/2237-101X0173209

Artigo recebido em 16 de junho de 2015 e aprovado para publicação em 22 de outubro de 2015.

* Universidade Federal Fluminense, Niterói - RJ, Brasil

Doutor em História pela Universidade Federal Fluminense (2011) e professor do Departamento de Educação e Ciências/Núcleo de História do Instituto Federal do Sudeste de Minas Gerais, campus de Juiz de Fora (MG). 


\section{Introdução}

Há momentos em que nos deparamos, na pesquisa em história, com algumas fontes que nos permitem aprofundar de uma maneira substancial uma proposta inicial de trabalho. Poderia dizer que este é o caso do opúsculo Jesuitas e Lazaristas, de autoria atribuída a Carlos [Charles] Habeneck (1836-1879), traduzido do francês para o português e publicado em Lisboa e espalhado por todo o país como se pode verificar em seu prólogo à segunda edição. Jesuitas e Lazaristas viria a confirmar senão uma relação — mesmo que indireta — um perfil político-clerical da passagem à modernidade e que envolvia essas duas congregaçôes religiosas contra as quais as ditas mentes ilustradas e adeptas [muitas vezes] do liberalismo e da maçonaria vinham a se debater. Fato comprovado, posto que podemos perceber a surpresa do editor em relação à grande aceitação que o opúsculo teve em Portugal, o que o faria desaparecer rapidamente das prateleiras dos livreiros lusitanos. ${ }^{1}$

Embora pudéssemos crer que este "folheto" viesse a se converter em uma publicação isolada no mar de escritos que circulavam na Europa naqueles tempos, acabamos por identificar também a edição de Os Lazaristas [Drama Original em Tres Actos]. De autoria do português, dramaturgo, romancista e historiador Antonio Ennes (1848-1901), tratava-se de uma peça teatral que teria sido representada pela primeira vez no Gymnasio Dramatico, de Lisboa, a 17 de abril de $1875 .{ }^{2}$ Os Lazaristas é ambientado na Lisboa do século XIX e tem em seu enredo uma narrativa em torno da educação religiosa que era dada às elites portuguesas por intermédio das Irmãs da Caridade, portanto, à educação Lazarista, que também seria abordada por Habeneck. ${ }^{3}$

A peça de Ennes viria ao Brasil, mas sua encenação seria vetada pelo Conservatório Dramático do Rio de Janeiro. O parecer de Cardoso de Menezes (1827-1915), datado de 21 de junho de 1875, chama a atenção para a desqualificação que a peça impunha aos religiosos da "família vicentina" no Brasil. Para o parecerista, a atuação destes no império seria muito importante pois

[...] tem revelado digna de sua missão apostólica, quer doutrinando no legítimo temor de Deus alumnos de ambos os sexos, que se tornam bons chefes de família e membros úteis da nação, sendo pela mesma sociedade dada a muito orphãos gratuita e desvelada educação e empregos adoptados á condição dos educados; quer velando nos hospícios com exemplar abnegação á cabeceira dos doentes, aos quaes proporciona remédios do corpo e consolaçóes da fé. ${ }^{4}$

\footnotetext{
${ }^{1}$ HABENECK, Carlos. Jesuitas e Lazaristas. Segunda edição aumentada de Os jesuítas em 1860. Lisboa: Typ. de J. G de Souza Neves, Rua do Caldeira, 1862, p. 5-6.

${ }^{2}$ ENNES, Antonio. Os Lazaristas. Drama original em tres actos. Rio de Janeiro: Imprensa Industrial, s/d.

${ }^{3}$ HABENECK, Carlos, Jesuitas e Lazaristas, op. cit., p. 17-18 e 21.

${ }^{4}$ Acervo da Fundação Biblioteca Nacional (AFBN). Setor de Obras Raras. ENNES, Antonio. O conservatório dramático do Rio de Janeiro e o drama Os Lazaristas. Carta ao Sr. Conselheiro Cardoso de Menezes. Lisboa: Typographia do Jornal — O Paiz. Rua do Alecrim, 89, 1875, s/p.
} 
Aqui podemos perceber que as fontes se cruzam. Para além de sua própria produção e do próprio consumo literário, o tema chama-nos a atenção: os Lazaristas e, mais especificamente, o instituto religioso dos Lazaristas e suas relaçóes com o ensino e as redes de socorro e assistência aos pobres. E se cruzam mais ainda se observamos os debates travados na imprensa da Corte e que poderiam ser estendidos para as mais diversas regióes do vasto Império tropical de Pedro II.

\section{Os Lazaristas e o ultramontanismo no Império do Brasil}

Podemos dizer que a principal diocese governada pelos padres da Missão foi Mariana, na província de Minas Gerais, da qual esteve à frente desde 1844 D. António Ferreira Viçoso (1787-1875), e pela qual a reforma ultramontana se afirmaria. A Arquidiocese da Bahia e as dioceses do Maranháo, Ceará e Rio Grande do Sul também teriam destaque neste panorama. No caso da Corte, embora já convivesse com Lazaristas desde a década de 1810, quando os padres Manoel Bernardo Ribeiro de Brito e José Cardoso Pinto assumiriam brevemente o reitorado do Seminário São José entre 1810-1814, é relevante pensar a presença da Congregação, de maneira definitiva a partir de 1868, quando então passaram ao governo da diocese do Rio de Janeiro a Dom Pedro Maria de Lacerda (1830-1890), discípulo de D. Viçoso, iniciando-se assim um longo período de reformas nas suas instituiçôes clericais. ${ }^{5}$

O olhar ultramontano (ou romanizador como queiram) das ordens religiosas, cujos noviços eram formados em conventos europeus, sobretudo em uma França do século XIX [muitas vezes] livre do galicanismo, ${ }^{6}$ começou a ver a necessidade de se intervir no clero nacional, envolto numa série de "vícios" de origem. Estes "vícios" podem ser entendidos a partir da própria formaçấo do clero imperial, de influências pombalinas e regalistas e que o levavam a um envolvimento com a política expresso, por exemplo, no movimento independentista brasileiro, estendendo-se pelo período regencial afora.

Trata-se aqui de entender o ultramontanismo não somente como defensor de uma maior concentraçáo de poder nas mãos do papado, mas contra uma série de outros fatores que eram considerados "perigosos" para a Igreja, entre os quais estavam, além do galicanismo e do regalismo citados anteriormente, o jansenismo, a maçonaria, o deísmo, o racionalismo, o protestantismo, o socialismo e o(s) liberalismo(s) e sua(s) proposta(s) de liberdade de religião

\footnotetext{
5 OLIVEIRA, Anderson José Machado de. Os bispos e os leigos: a reforma católica e as irmandades no Rio de Janeiro. Revista de História Regional, Ponta Grossa, v. 6, n. 1, p. 147-160, 2001. Disponível em: <http:// www.revistas2.uepg.br/index.php/rhr/article/view/2122>. Acesso em: 22 jan. 2015.

${ }^{6}$ VIEIRA, David Gueiros. O protestantismo, a maçonaria e a questão religiosa no Brasil. 2. ed. Brasília: EdUnB, s/d, p. 28.
} 
e imprensa e casamento civil. ${ }^{7}$ Portanto, ideias que se direcionavam para um processo de laicização dos Estados nacionais do Oitocentos.

Entende-se ainda que o ultramontanismo buscava aproximar a Igreja daquilo que havia sido preconizado ao tempo do Concílio de Trento (1545-1563), mas que em função da uma série de questóes político-culturais não chegou a ser completamente implementado. Político-culturais no sentido em que as concessóes feitas pela própria Igreja quanto ao padroado, ainda em fins da Idade Média, reforçada pelos aspectos teóricos que apoiavam a supremacia dos próprios Estados nacionais sobre as orientaçóes emanadas de Roma, no que se pode entender como o regalismo-galicanismo, acabaram por transformar as ordens religiosas em partes constituintes do próprio corpo administrativo e, ao menos parcialmente, submissas ao poder temporal. No entender dos historiadores que durante boa parte do século XX se incumbiram de escrever a história da Igreja, este processo histórico em que estivera sob o regalismo teria-lhe sido algo extremamente prejudicial, tornando-a refém do Estado e contribuindo para que os costumes, para que as verdadeiras práticas a que os religiosos deveriam seguir e difundir fossem deturpadas. ${ }^{8}$

A atuação dos Lazaristas em prol da reforma ultramontana viria a provocar em um segmento notadamente letrado e ilustrado não somente da Corte e que se comunicava por meio do periodismo, uma sequência considerável de críticas à ação da Igreja e, em específico, aos bispos que estariam encampando o referido movimento. Em uma destas, lê-se no Jornal do Comércio:

A falta de instrucção popular, o abandono em que o governo tem deixado os interesses moraes da nação, e o desleixo com que olha para as cousas do povo, tudo lhes abrio vastíssimo campo para as suas ambiciosas emprezas, que os leva a uma luta constante contra a sociedade civil, contra a qual empregão as suas tres mais poderosas armas, o confissionario, a instrucção da infância e a espionagem, por meio de seus discípulos e confessadas, a quem corrompem e viciáo pelo mais estúpido fanatismo e grosseira superstição.

Começáráo a sua propaganda, e os seus agentes, a sua guarda avançada que aportou ás nossas praias, forão as denominadas Irmãs da Caridade, de S. José, e outras idênticas, que afastandose dos princípios de suas instituição que desnaturão, apossando-se da instrucção feminista, principalmente das filhas de famílias abastadas, vão plantando nos espíritos infantis do sexo frágil as ideas e princípios fanáticos do jesuitismo.

A esta guarda avançada acompanharão e seguirão-se os lazaristas, capuchinhos e outros frades estrangeiros fugidos de suas terras na velha Europa, quando o sol da liberdade lhes offusca a falsa estrella da Roma papista, e que temos consentido sejāo impostados no Brazil. [...].

\footnotetext{
${ }^{7}$ Ibidem, p. 33.

${ }^{8}$ TÔRRES, João Camilo de Oliveira. História das ideias religiosas no Brasil. A Igreja e a sociedade brasileira. São Paulo: Editorial Grijalbo Ltda, 1968, p. 34.

${ }^{9}$ AFBN. Setor de Periódicos. Jornal do Comércio. 20 de abril de 1872, p. 2, col. 8.
} 
As impressóes deste periódico nos trazem informaçóes ricas no aspecto do debate ideológico e na quantidade em que aparecem. Isto não é por acaso. Os ataques da maçonaria intensificam-se ao ultramontanismo e ao [pretenso] jesuitismo, "encarnado" nos Lazaristas e no padre Lacerda, sobretudo após este ter proibido o reverendo José Luiz de Almeida Martins (1836-?) de pregar e confessar. Almeida Martins era orador da maçonaria e exaltaria a figura do visconde do Rio Branco (1819-1880) em uma de suas preleçôes à frente do Grande Oriente Brasileiro do Vale do Lavradio em virtude da aprovação da Lei Rio Branco, mais conhecida em nossos manuais acadêmicos por Lei do Ventre Livre, de 28 de setembro de 1871. Estava em curso o que a historiografia do século XX chama de "a questão religiosa". ${ }^{10}$

Qual seria o problema em homenagear Rio Branco? Almeida Martins era o único padre-maçom na diocese do Rio de Janeiro? Certamente não. Assim também o próprio D. Pedro Maria de Lacerda já havia exortado o governo imperial pela aprovação da Lei do Ventre Livre, mesmo porque a princesa Isabel, de quem era muito próximo, regia o governo no tempo em que o documento foi aprovado. ${ }^{11}$ Cabe-nos ainda mais algumas perguntas: por que de tamanhas críticas aos Lazaristas e suas Irmãs da Caridade por atuarem em instituições de ensino e assistência? Procuramos respostas a essas questóes levando-se em consideração a hipótese de que as necessidades impostas à modernizaçáo do império implicavam reformas que incidiriam sobre instituiçôes entáo controladas pela Igreja, como seriam os casos da escola e da assistência.

E estas seriam veículos pelos quais a Igreja iria atuar sobre outra instituição modelar: a família. Afastar o ultramontanismo e o clero ultramontano do convívio com as crianças e os pobres seria uma forma de se reformular a família, elemento importante para um império que se via às voltas com a necessidade de novos braços para a lavoura agrícola. Essa discussão nos leva a pensar um conceito para a própria ideia de questáo religiosa: longe de se circunscrever à década de 1870, o que procuraremos discutir é que o ocorrido neste tempo foi reflexo de um processo de uma duraçáo bem mais longa e que remontaria a um período de reformas datado já dos anos 1840 e que teria à sua frente José Tomás Nabuco de Araújo (1813-1878), sobretudo ao tempo em que assumiria a pasta da Justiça.

\section{O campo político imperial: o regalismo e a reforma da Igreja}

Torna-se relevante aqui o exame de um conjunto de documentos que Nabuco de Araújo nos deixou e que se encontram disponíveis para a pesquisa no Instituto Histórico e Geográfico Brasileiro (IHGB). A análise desta documentação revela que havia uma intenção

\footnotetext{
${ }^{10}$ VILLAÇA, Antonio Carlos. História da questão religiosa no Brasil. Rio de Janeiro: Francisco Alves, 1974.

${ }^{11}$ SCHUBERT, Guilherme. A provincia eclesiástica do Rio de Janeiro. Rio de Janeiro/Belo Horizonte: Agir Editora, 1948, p. 12-16.
} 
expressa em se repensar a relação Estado e Igreja já a partir da década de 1840, partindo-se, portanto, de uma reforma encampada pelo Estado. Desde este tempo, já se identifica uma preocupação em se regular esta entrada do clero estrangeiro no país, o que se pode verificar pelo Decreto no 285 de 21 de julho de 1843 pelo qual ficava autorizado o governo a mandar vir da Itália capuchinhos para que fossem distribuídos pelas províncias em missões. ${ }^{12}$

A este respeito, em 12 de março de 1855, o Visconde de Abaeté (1798-1883) assinalava, em cópia anexa ao Aviso dirigido pelo Ministério dos Negócios Estrangeiros ao Ministério da Justiça, a grande resistência de Roma em aceitar as intervençóes do governo do império nas missóes dos Capuchinhos, contribuindo, assim, para uma série de dificuldades na gestão das ordens religiosas no Brasil e um longo debate que iria se acentuar pelas décadas subsequentes. ${ }^{13}$ Naquele mesmo ano, em Circular de 19 de maio de 1855, o governo suspendia as ordens religiosas de aceitar noviços em seus conventos, culminando também, em 1870, na proibição de entrada no país de noviços brasileiros que tivessem sido ordenados no exterior. ${ }^{14}$ Neste período, o governo imperial e a Santa Sé caminhariam para um longo debate visando a uma concordata que nunca chegaria. ${ }^{15}$

Toda esta documentação traz ainda de maneira ordenada a legislação, minutas de leis e decretos, cartas, rascunhos e anotaçóes, recortes de jornal, entre outros, feitas pelo senador Nabuco ao longo de sua atuação política no Segundo Reinado. A grande preocupação do governo imperial, ao que nos parece, seria trabalhar com ordens religiosas que se voltassem para o exercício de uma função ou atividade catequética entendida como um apoio na esfera administrativa.

Logo, seria preciso observar sua capacidade de obedecer às orientaçóes feitas pelos governos, sejam estes o governo geral ou os governadores provinciais, conforme ficaria expresso em um rascunho de minuta de um [possível] decreto que em seu artigo 10ํ dizia:

Os missionários, no que toca ao arranjo material e economia dos aldeamentos observarão as ordens dos Presidentes das Províncias, e a elles darão anualmente hum relatório circunstanciado do estado dos mesmos aldeamentos, bem como prestarão contas das quantias recolhidas com destino á catechese. ${ }^{16}$

\footnotetext{
${ }^{12}$ Disponívelem: <http://legis.senado.gov.br/legislacao/ListaTextoIntegral.action?id=66122\&norma=82038>. Acesso em: 22 jan. 2015.

${ }^{13}$ IHGB. Documentos sobre assuntos religiosos compilados pelo Conso José Tomás Nabuco de Araújo, e ordenados em livro, p. 37.

${ }^{14}$ MICELI, Sergio. A elite eclesiástica brasileira. Rio de Janeiro: Bertrand Brasil, 1988, p. 17.

${ }^{15}$ SANTIROCCHI, Ítalo Domingos. Dois poderes em desacordo: o fracasso da Concordata de 1858. Anais da Associação Brasileira de História das Religiōes. Religião, carisma e poder: As formas da vida religiosa no Brasil - 29/05 a 01/06/2012, São Luís, v. 13, s/p., 2012. Disponível em: <http://www.abhr.org.br/plura/ojs/ index.php/anais/article/viewFile/612/514>. Acesso em: 28 jan. 2015.

${ }^{16}$ IHGB. Documentos sobre assuntos religiosos compilados pelo Conso José Tomás Nabuco de Araújo, e ordenados em livro, p. 39-40.
} 
Esta documentação revela-nos ainda uma série de outras correspondências endereçadas pelo senador Nabuco ao "Internúncio de Sua Santidade" no Brasil e ao ministro da Justiça tentando algum acordo em relação ao melhor modelo para que as missôes religiosas se dessem no Império, datadas sequencialmente de 3 e 14 de fevereiro e 4 de março de $1857 .{ }^{17}$ Nabuco guardaria também entre seus documentos um impresso cujo texto seria assinado pelo padre José von Reis, fazendo referência ao perfil da Ordem de Santa Cruz e sua atuação junto à educação. O texto seria direcionado a Dom Pedro II, pedindo-lhe permissão para que a Ordem se instalasse no Brasil.

A proposta de reforma no ensino do [dito] padre von Reis nos parece preciosa, no sentido em que propôe algo bem diferente em termos do que aquilo que a tradição escolástica jesuíta até então havia oferecido ao Brasil. Propunha, assim, que fosse fundado um "Instituto Philantropico", meio eficiente e menos dispendioso para se fazer cumprir aquilo que o Imperador, em uma de suas "falas do trono", havia recomendado, isto é, solucionar o problema da falta de braços para a lavoura [quase] toda agrícola do país, argumentava o prelado. ${ }^{18}$

Padre von Reis diria ainda que a Ordem de Santa Cruz estaria atenta aos progressos científicos daquele século XIX, tendo a possibilidade de se publicar compêndios de pedagogia, metódica, catequese, exegese, arqueologia, entre outros, e que seria, ainda, uma boa opçáo para se trabalhar com os índios e promover a gradual reforma do clero de que tanto se falava naquela tempo. Se a Ordem viria ou não a atuar no império não nos é possível afirmar, entretanto a guarda do documento por Nabuco de Araújo, assim como a própria forma que a Ordem promove seus trabalhos para que o imperador permitisse sua atuação no Brasil, nos leva a crer que algo novo estaria sendo pensado tendo em vista o que até o momento vinha-se oferecendo em termos de parceria religiosa.

Nabuco de Araújo já havia aberto também um diálogo com os bispos do Pará [José], do Maranhão [Manoel], Cuiabá [José], Pernambuco [João], Goiás [Francisco] e Mariana [António] em uma série de correspondências confidenciais a eles endereçadas. Dentre esses diálogos, vejamos a resposta do bispo de São Paulo, datada de 19 de outubro de 1853. Estando em visita a Paraibuna (SP), o bispo daquela diocese, Dom Antônio Joaquim de Melo (1791-1861), teceria algumas consideraçóes muito relevantes para as possíveis reformas que se desejavam fazer, necessárias em seu entender, posto que o "espírito do catolicismo está quasi extinto no Brasil". Dizia o bispo que via com bons olhos aquela tentativa de disciplinar as ordens religiosas, embora divergisse de Nabuco quanto à forma como essa reforma deveria se dar, pois entendia que reformar a vivência religiosa destes que já atuavam no Império era algo muito complicado, uma vez que muitos deles haviam entrado para a Igreja sem nenhum tipo de vocação.

\footnotetext{
${ }^{17}$ Ibidem, p. 41; 43-44 e 45-58.

${ }^{18}$ Ibidem, s/p.
} 
Em suma, D. Antônio desejava a secularização das ordens religiosas, passando o governo imperial a destinar apenas uma diária para a sustentação dos clérigos já atuantes no país e o restante ficaria a cargo da Igreja que, por intermédio do Santo Padre, mandaria ocupar antigos conventos em desuso com padres vindos da Europa. Entre estes, D. Antônio cita os "Redentoristas de Santo Afonso Ligório, os Dominicanos e os Barbadinhos [frades Capuchinhos franciscanos], os congregados de São Vicente de Paulo, ou Lazaristas, (sic) de São Philipe Neri". Todos que, em sua visão, teriam a propagação da fé por seu fim principal. A carta de Dom Antônio nos dá um panorama muito interessante em relação ao que se pensava sobre a presença das ordens religiosas no Brasil. Vejamos que ele não cita a Companhia de Jesus, embora entenda em sua resposta a Nabuco de Araújo que este seria o instituto religioso mais completo para que a dita reforma religiosa viesse a ocorrer. Entretanto, "o Brasil os detesta", disse o bispo."

Neste contexto, a Congregação da Missão e das Irmãs da Caridade também se colocaria como uma alternativa ao processo de reforma religiosa, o que pode ser verificado a partir de uma correspondência de seu Superior, padre Joáo Batista Étienne (1801-1874), ${ }^{20}$ oriunda de Paris e datada de $1^{\circ}$ de janeiro de 1846 — portanto, "inaugurando" as intençóes da "Companhia" naquele ano [santo] e endereçada aos seus padres no Brasil. Assim sendo, Étienne entendia que aos Lazaristas cabia preocuparem-se mais com as questôes espirituais do que temporais, além de obrar nas missóes sempre em nome de Cristo - tal qual Vicente de Paulo - e procurando-se sempre em esquivarem-se de questóes mundanas, sobretudo num tempo em que a filosofia apresentava um vasto e atrativo "cardápio" de novidades, ideias e ideologias políticas. ${ }^{21}$

Neste percurso, o Superior destacava a relação dos "filhos de São Vicente" com os poderes temporais em outros países. No México, a atenção dada a não intervenção do Estado na administração do clero regular era evidente. Étienne destaca em seu texto a legislação daquele país, que regulava a situação da Congregação e que lhes permitiria "desenvolver-se livremente e estender-se a todos os pontos da república”, levando-se em consideração ainda o apoio do arcebispo da Cidade do México que havia doado-lhes uma casa para edificação da obra das missóes, assim como teria trabalhado para que tivessem uma renda considerável que lhes sustentava no país. ${ }^{22}$

Tão logo o império passaria também a conviver com os Lazaristas franceses. Em 1848, portando um requerimento de D. Viçoso, os sacerdotes e futuros bispos Luís Antônio dos Santos, Pedro Maria de Lacerda e João Antônio dos Santos iriam pessoalmente falar com o

\footnotetext{
${ }^{19}$ Idem.

${ }^{20}$ Udovic. Edward R., Jean-Baptiste Etienne and The Vincentian Revival. Chicago: The Vincentian Studies Institute, 2001. Disponível em: <http://via.library.depaul.edu/cgi/viewcontent.cgi?article=1000\&context=jean baptiste>. Acesso em: 21 fev. 2015.

${ }^{21}$ Província Brasileira da Congregação da Missão (PBCM). Carta do Superior da Congregação da Missão. Paris, 1o de janeiro de 1846, p. 2 e 3.

${ }^{22}$ PBCM. Carta do Superior da Congregação da Missão. Paris, 1o de janeiro de 1846, p. 12.
} 
Superior da Missão na França. Depois dessa viagem aportaria no Rio de Janeiro, em 9 de fevereiro de 1849, cinco padres, três irmãos coadjutores e doze Irmãs da Caridade. ${ }^{23}$ Alguns anos depois, José Clemente Pereira (1787-1854), autorizado pela irmandade da Santa Casa de Misericórdia do Rio de Janeiro, iria contratar, em julho de 1852, sessenta filhas de São Vicente de Paulo para se encarregarem do serviço do novo hospital e enfermarias anexas, enfermaria da Saúde e do novo Hospício de Pedro II. Quando da provedoria do Marquês de Paraná (1801-1856), a estas também seria confiada a Casa dos Expostos e, em 1857, o recolhimento das órfās, pelo provedor marquês de Abrantes (1796-1865), totalizando-se 98 irmãs atuantes nas obras assistenciais da Corte naquele ano. ${ }^{24}$

Outro assunto recorrente nesta documentação dizia respeito ao patrimônio da Igreja e à possibilidade das chamadas Corporaçôes de Máo-morta de se disporem do mesmo. Entenda-se por definição de Corporação de Mão-morta aquelas

[...] instituições de caráter permanente, com fim religioso, de beneficência, de caridade, tais como irmandades, confrarias, igrejas, mosteiros, capelas, asilos e outros semelhantes. Em tais entidades, por seu caráter perpétuo, os bens não podiam mudar de mãos, e, por isso, constituiam riqueza morta. ${ }^{25}$

Um opúsculo intitulado Ao Senado Brasileiro: o Dom Abade de S. Bento (1869) ${ }^{26}$ e um número razoável de recortes de jornais em que se discutia a alienação dos bens religiosos incluindo-se aqui um a respeito da situação religiosa no México - nos levam a perceber o interesse de Nabuco em estudar este assunto embora a questão da governança sobre os bens eclesiásticos não fosse propriamente uma novidade, como podemos ver nos debates a seguir. Já em 1830, em lei datada de 9 de dezembro, declarava-se "nullos e de nenhum effeito os contractos onerosos e alienaçôes feitas pelas Ordens Regulares sem preceder licença do Governo", ${ }^{27}$ embora fosse permitida, de acordo com o artigo 44 da Lei no 369 , de 18 de setembro de 1845 ,

\footnotetext{
${ }^{23}$ ZICO, José Tobias. Caraça: peregrinação, cultura e turismo (1770-1976). 5. ed. Contagem, MG: Editora Littera Maciel, 1988, p. 59.

${ }^{24}$ PBCM. Biblioteca do Caraça. ABRANTES [Marquês de]. As Irmãs de Caridade no Rio de Janeiro. Discurso pronunciado no Senado por S. Ex. o senhor Marquez de Abrantes na sessáo de 22 de agosto. Rio de Janeiro: Typographia de F. de Paula Brito, 1859, p. 5 e 6.

${ }_{25}$ Disponível em: <http://www2.camara.leg.br/legin/fed/decret/1824-1899/decreto-1225-20-agosto-1864-554707-norma-pl.html>. Acesso em: 24 jan. 2015.

${ }^{26}$ Ao Senado Brasileiro: O Dom Abade de S. Bento. Rio de Janeiro. Typ. Do Diário do Rio de Janeiro, 16 de agosto de 1869.

27 Disponível em: <http://www2.camara.leg.br/legin/fed/lei_sn/1824-1899/lei-38030-9-dezembro-1830-565770-publicacaooriginal-89498-pl.html>. Acesso em: 24 jan. de 2015.
} 
[...] a quaesquer Corporaçóes de mão morta permutar seus bens de raiz por Apolices da mão morta permutar seus bens de raiz por Apolices da divida publica interna fundada, as quaes serão intransferíveis, ficando-lhes, desde já, concedido hum abatimento de metade da sisa devida pelas ditas permutações. ${ }^{28}$

Ambas legislações eram reguladas pelo Decreto n⿳0 655, de 2 de novembro de 1849, ${ }^{29}$ e assinadas por Eusébio de Queirós (1812-1868), ministro e secretário de Estado dos Negócios da Justiça. ${ }^{30}$ Essas medidas acabavam encontrando opositores de peso no âmbito do campo político imperial, como fora o caso do [ainda] deputado pela província da Maranhão, Cândido Mendes (1818-1881) — aqui chamado um "ultramontano de casaca". Em 20 de julho de 1869, o deputado faria um pronunciamento à Assembleia Imperial, questionando a proposta de lei orçamentária para o ano financeiro de 1869-1870, no tocante à limitação que era imposta às corporaçóes monásticas quanto à conversão dos valores auferidos com a venda de seus bens somente em apólices da dívida pública.

O ponto central da discussão seria a liberdade de ação que, no Império, a Igreja não teria. Cândido Mendes, rebatendo a um "aparte” do deputado Duque-Estrada Teixeira, ${ }^{31}$ destaca como em outros países em que inexiste a tutela da Igreja pelo Estado as ordens monásticas têm melhor atuação frente às missões de catequese a que se propóem. Em suma, há um debate sobre questóes de direito, notadamente envolvendo o direito canônico e a legislação imperial de base regalista que impedia a Igreja o direito de possuir bens. ${ }^{32}$

Em 5 de abril de 1856, o visconde do Uruguai (1807-1866) escreveria de Paris ao ministro dos Negócios Estrangeiros — José Maria da Silva Paranhos (1819-1880) — com o pedido de que comunicasse "ao Sr. Nabuco" do conteúdo da correspondência, uma vez que, dizia o visconde, talvez o assunto lhe fosse de interesse. Nesta carta, Uruguai narra seu encontro com o papa Pio IX (1792-1878) e seu secretário de Estado, cardeal [ultraconservador] Giacomo Antonelli (1806-1876). Não se tratava de uma visita diplomática e oficial, entendendo-se

${ }^{28}$ Disponível em: <http://www2.camara.leg.br/legin/fed/lei/1824-1899/lei-369-18-setembro-1845-560471publicacaooriginal-83297-pl.html>. Acesso em: 24 jan. 2015.

${ }^{29}$ Disponível em: <http://www2.camara.leg.br/legin/fed/decret/1824-1899/decreto-655-28-novembro-1849-559892-publicacaooriginal-82327-pe.html>. Acesso em: 24 jan. 2015.

${ }^{30}$ Esta questão seria discutida ainda no Decreto no 1.911, de 28 de março de 1857, disponível em: <http:// www2.camara.leg.br/legin/fed/decret/1824-1899/decreto-1911-28-marco-1857-557928-publicacao original-78694-pe.html>. Acesso em: 25 jan. 2015; no Decreto no 1.225, de 20 de agosto de 1864, disponível em: $<$ http://www2.camara.leg.br/legin/fed/decret/1824-1899/decreto-1225-20-agosto-1864-554707-norma-pl. html>. Acesso em: 25 jan. 2015; e Decreto no 4.453, de 12 de janeiro de 1870, disponível em: <http://www2. camara.leg.br/legin/fed/decret/1824-1899/decreto-4453-12-janeiro-1870-552811-publicacaooriginal-70305-pe.html>. Acesso em: 25 de jan. 2015.

${ }^{31}$ TEIXEIRA, Duque-Estrada. Questão religiosa interpellação do deputado Duque Estrada Teixeira sessão de 6 de julho de 1874 Debate entre o mesmo deputado e o Ministro do Imperio. Rio de Janeiro: Typ. Imperial e Constitucional de J. Villeneuve E C., 1874.

${ }^{32}$ AFBN. ALMEIDA, Cândido Mendes de. Discurso pronunciado na sessão de 20 de julho de 1869 sobre as ordens religiosas. O Apóstolo. 22 de agosto de 1869, p. 269-271. 
que Paranhos havia incumbido a Uruguai desta missão, extraoficial, a Roma, tanto que a mesma ocorrera em um período de férias do visconde. Depreende-se do documento que a visita tinha um caráter estratégico: por um lado, Uruguai procurava sondar como o papa estava vendo a situação da Igreja no Brasil ou como estavam lhe sendo enviadas notícias sobre a Igreja no Brasil; e, por outro, procurava esclarecê-lo melhor sobre o que lhe vinha chegando de informaçóes.

A situação das ordens religiosas e o problema da formação do clero no Brasil conduziram boa parte da conversa e Pio IX chegou a sugerir ao visconde que os jesuítas poderiam ajudar no processo de reforma do clero no Brasil. Uruguai disse a Paranhos que neste momento da conversa houve um pequeno dissabor, uma vez que procurou mostrar ao papa que esta não era a melhor ideia, pois seria "exótico na América e no Brasil uma crusada contra uma dusia de padres estrangeiros, diferenciados, porque tivessem a denominação de jesuítas, ou qualquer outra" ${ }^{33}$

Um assunto, porém, não foi tratado por Uruguai com Pio IX. Dizendo que entre tudo que conversaram o papa náo tocou na questáo dos casamentos mistos, disse ter se silenciado a respeito do fato, escrevendo a Paranhos que seria uma "materia sobre a qual encontraremos difficuldades”. A década de 1850 seria emblemática para a discussão dos casamentos mistos. Os últimos escravos oriundos do tráfico Atlântico entravam nos portos imperiais e alternativas deveriam ser apresentadas pelo governo para suprir a lavoura e os demais setores que passavam a carecer de máo de obra. Os Estados europeus passavam a ser alvo das políticas imigrantistas nacionais, mas o governo esbarrava num obstáculo, qual seja como validar os casamentos de imigrantes acatólicos, uma vez que não havia até aquele momento nada que regulasse e validasse essa relação. Em suma, registra-se aqui mais um problema de direito, seja ele civil, assim como um problema de direito canônico no tocante a que poder caberia legislar sobre um sacramento, qual seja o casamento. Como o campo político imperial iria enfrentar este dilema?

É importante aqui fazer uma pequena incursão por este debate e para isto nos valemos da ata do Conselho de Estado de 29 de maio de 1856, em que foi discutida a questão do casamento civil entre protestantes e católicos — os chamados casamentos mistos - e de acatólicos. O problema, como dissemos, era que o casamento ainda náo era claramente entendido como um contrato e sim como um sacramento. Na fala do visconde de Maranguape (1795-1875), por exemplo, percebe-se este tipo de inclinação. Em suas próprias palavras, o casamento católico seria justificado senão pelo "Manual do Catolicismo, do Concilio de Trento", desqualificando o casamento civil, inspiração liberal que se assentou desde a Revolução Francesa, a "[Revolução] mais horrível, que tem visto o mundo". O que fica patente na fala do visconde seria a defesa de que o Estado não poderia desobrigar, sobretudo ao católico

\footnotetext{
${ }^{33}$ IHGB. Documentos sobre assuntos religiosos compilados pelo Conso José Tomás Nabuco de Araújo, e ordenados em livro, p. 185.
} 
que vivesse no império, às dispensas, isto é, que se casasse somente no civil ou que obrigasse legalmente os noivos a contraírem matrimônio obedecendo primeiramente à lei civil. Evidentemente, o visconde não estaria contra as necessidades ululantes do mercado de mão de obra, mas perguntava se competiria àquele conselho - leia-se, de um modo geral, ao poder temporal — "tirar o caráter de santidade, que o casamento deveria ter para o bem da família e da sociedade dispensando-o de todas as cerimônias religiosas, quando esses esposos se contentem com o contrato civil?" 34

Já o marquês de Olinda (1793-1870) não via nem a necessidade de que se estabelecesse um projeto desta tipologia, tendo em vista não haver ainda demanda suficiente e, além disso, mesmo havendo, os bispos não ofereceriam resistência à concessão de dispensas, entendia o marquês. Respeitando a opinião de Olinda, Eusébio de Queirós - que atuava como relator do projeto de lei que o Conselho de Estado passava a discutir - disse que haveria um engano de sua parte, pois grande número de acatólicos já habitava o império, sendo de seu conhecimento casos, sobretudo em São Paulo, em que alemães enfrentavam dificuldades para celebrar seus casamentos mistos, tendo muitos deles procurado tabeliães para firmar os contratos nupciais. ${ }^{35}$ A questão, para Eusébio de Queirós e muitos outros políticos do império, era quanto à validade deste tipo de casamento e, mais uma vez, a questão da família seria retomada, pois, além da ilegitimidade da prole e de seus direitos quanto à herança, não teria legitimidade a convivência dos cônjuges, sendo que um poderia abandonar o outro e, sobretudo, a mulher, "que se julgava casada, conhecerá tarde que não passou de simples concubina”. ${ }^{36}$

Recorrentes seriam também as consultas dos bispos em relação à nomeação de padres — os vigários colados - para as paróquias, curatos, canonicatos etc., de suas dioceses. D. Viçoso escreveria ao Conselho de Estado, o que foi discutido na sessão de 2 de outubro de 1856, solicitando a impugnaçáo da escolha de José de Souza e Silva Roussin feita por D. Pedro II para cônego, posto que o mesmo era "amancebado" e levava sua filha "por mãos, às procissóes, vestida de anjo, com público escândalo da cidade". ${ }^{37}$

$\mathrm{O}$ debate se processou de modo que alguns defendiam o direito do imperador de nomear quem quer que fosse para os cargos eclesiásticos, no entanto, os marqueses de Jequitinhonha e de Olinda entraram no mérito de que esta escolha deveria levar em consideração predicados, embora não tenham "derrubado" a prerrogativa constitucional do imperador. Em suma, em 28 de julho de 1857, quando o marquês de Olinda já ocupava a Presidência do Conselho de Estado e Diogo Pereira de Vasconcelos (1812-1863) estaria à frente do Ministé-

\footnotetext{
${ }^{34}$ ATAS do Conselho de Estado Pleno. Terceiro Conselho de Estado (1850-1857), p. 181. Disponível em: $<$ http://www.senado.gov.br/publicacoes/anais/pdf/ACE/ATAS4-Terceiro_Conselho_de_Estado_1850-1857. pdf $>$. Acesso em: 23 jun. 2014.

${ }^{35}$ Ibidem, p. 190.

${ }^{36}$ Ibidem, p. 191.

${ }^{37}$ Ibidem, p. 8.
} 
rio da Justiça, o bispo de Mariana foi ordenado a cumprir a decisão imperial que já lhe havia sido enviada em 1855, nomeando Roussin. Entretanto, o tema voltaria ainda ao Conselho de Estado em 1858 e, com o apoio do visconde de Uruguai e de Jequitinhonha, foi levada em consideração a questão moral do padre Roussin. ${ }^{38}$

Outra consulta interessante feita por D. Sebastiâo Dias Laranjeira, também Lazarista, na sessão de 8 de março de 1862. O visconde de Sapucaí (1793-1875) leu então o parecer da Seçấo dos Negócios do Império, externando a preocupação assinalada por D. Sebastiáo em relação às freguesias mais pobres de sua diocese, que se encontravam vagas em função da inexistência de clero nacional habilitado e da impossibilidade de ocupá-las com padres estrangeiros, tendo em vista que a estes não era destinada côngrua. D. Sebastiáo pedia licença para colar os estrangeiros nestas freguesias, recebendo o mesmo que o clero nacional, prometendo substituí-los na medida em que fossem surgindo candidatos nacionalmente habilitados.

Entendendo as dificuldades apontadas, o parecer foi favorável à proposta do bispo, mas o visconde de Albuquerque atentou para o fato de que estrangeiros não deveriam ocupar funçôes públicas no império, sendo isto vedado pela Constituição em seu artigo 179, tendo sido acompanhado em seu posicionamento pelo visconde de Maranguape. Já os viscondes de Abaeté e de Jequitinhonha manifestaram-se a favor do parecer de Sapucaí, embora Jequitinhonha tenha pedido para que ficasse claro no parecer que isto não deveria tornar-se uma regra para outras dioceses do império. Por fim, o visconde de Albuquerque chama a atenção para a necessária vigilância dos bispos para com os estrangeiros, refletindo sobre os jesuítas e sua condição de missionários. No encerramento da discussão, intrigado - ao menos pareceu-nos - Albuquerque questiona ao Conselho por que o bispo de São Pedro "só pede gratificaçâo para os estrangeiros?”. ${ }^{39}$

$\mathrm{Na}$ conversa de Uruguai com Pio IX, este tema havia sido abordado. Ao contrário do que vinha ocorrendo em Sáo Paulo - para o qual reclamou falta de apoio das autoridades provinciais —, o papa revelou-se preocupado com a situaçáo das dioceses brasileiras e com a inoperância de alguns de seus bispos, citando em específico o caso do Rio de Janeiro. Em 1856, a diocese de São Sebastiẫo era governada por Manuel do Monte Rodrigues de Araújo (1798-1863) — conde de Irajá —, "homem de alguma instrução", disse Pio IX, mas que nada sabia sobre sua moralidade, sendo-lhe recorrentes apenas notícias sobre a sua fraqueza, pois sabia que o mesmo havia deixado o bispado ao arbítrio de seu secretário. Tentando defender o governo imperial, Uruguai expôs a trajetória em que o clero nacional havia se formado, buscando no processo de colonizaçáo portuguesa um elo com as dificuldades que

\footnotetext{
${ }^{38}$ Idem. Nestas duas últimas notas estamos nos baseando na resenha feita por José Antonio Soares de Souza, a quem foi encomendada uma apresentação a esta edição das Atas do Conselho de Estado.

${ }^{39}$ ATAS do Conselho de Estado Pleno. Terceiro Conselho de Estado (1857-1864), p. 171-172. Disponível em: $<$ http://www.senado.gov.br/publicacoes/anais/pdf/ACE/ATAS5-Terceiro_Conselho_de_Estado_1857-1864. pdf $>$. Acesso em: 27 jun. 2014.
} 
se apresentavam naquele presente. Ademais, D. Pedro II estava "arrumando a casa" e era homem preocupado com o tipo de religioso que nomearia para o exercício clerical e disposto a entender-se com Roma quanto às ordens religiosas, ao que Pio IX demonstrou ter as melhores disposiçóes para entender-se com o governo do Brasil. ${ }^{40}$

O discurso, de 22 de agosto de 1859, do marquês de Abrantes, na tribuna do Senado, já nos leva a refletir, senão sobre conflitos propriamente ditos, mas sobre o que se pensava a respeito da entrada de religiosos estrangeiros no Império do Brasil. O pronunciamento de Abrantes dava-se em função dos questionamentos que lhe haviam sido feitos pelo primeiro secretário da casa, senador Ferreira Penna (1800-1867), do Amazonas, e por Antônio Luís Dantas de Barros Leite (1802-1860), senador por Alagoas, em relação à forma como estava se dando a administração das Irmãs da Caridade na Misericórdia do Rio de Janeiro. Entre críticas de levarem uma vida não necessariamente resignada à pobreza, as Irmãs da Caridade também eram acusadas de não tratarem com a devida caridade aos doentes que estariam sobre sua proteção.

Abrantes diz que as irmás deveriam impor dietas aos doentes que estavam sobre seus cuidados, mas que as reclamações dos mesmos eram fatos isolados. Em relação aos castigos, diz que "para manter a ordem nas enfermarias, entre outras regras disciplinares, eram admitidas a de castigar-se qualquer doente insubordinado e refractario com diminuição de parte da dieta, privação de sahir do leito, de passeiar, etc". Também entendia que não haveria problemas em doentes que trabalhavam quando estavam sobre cuidados médicos, pois isto ocorria também em outros hospitais e servia-lhes para "distracção e ocupação do espírito". $\mathrm{O}$ mesmo se daria em relação às acusaçôes de duas mulheres que diziam terem sido agredidas pelas irmãs por se recusarem ao trabalho, denúncias que entendia serem exageradas e as quais a própria polícia encarregara-se de desmenti-las. ${ }^{41}$

Em relação ao senador Dantas, este havia também questionado ao ministro dos Negócios Estrangeiros que a Congregação das Irmãs da Caridade estava adquirindo bens de raiz com o consentimento do governo, fato que não poderia ocorrer se esta fosse considerada corporação de mão-morta e, principalmente, sendo uma instituição estrangeira. Dirigiu-se ainda ao provedor da Santa Casa, neste caso, o próprio Abrantes, com o intuito de que ficasse atento para que as irmãs não perseguissem os não católicos que da caridade necessitassem. $\mathrm{O}$ exercício do magistério também seria alvo de seus questionamentos, posto que dizia desconhecer a presença das mesmas em escolas em qualquer outra parte do mundo e que, mesmo excetuando Portugal, já haviam sido feitas reflexóes por parte do ministro do rei no Parlamento daquele país. ${ }^{42}$

\footnotetext{
${ }^{40}$ IHGB. Documentos sobre assuntos religiosos compilados pelo Cons ${ }^{\circ}$ José Tomás Nabuco de Araújo, e ordenados em livro, p. 185.

${ }^{41}$ PBCM. Biblioteca do Caraça. ABRANTES [Marquês de]. As Irmãs de Caridade no Rio de Janeiro. Discurso pronunciado no Senado por S. Ex. o senhor Marquez de Abrantes na sessão de 22 de agosto, op. cit., p. 11 e 12. ${ }^{42}$ Ibidem, p. 16 e 17.
} 
Abrantes foi enfático em sua resposta ao senador Dantas. Em seu entendimento, a Congregação das Irmâs da Caridade não comprava nem vendia bens de raiz e as religiosas moravam em casas doadas pelos governos dos países em que viviam. $\mathrm{O}$ marquês entendeu que a compra da casa de Botafogo, em que se achava montado e dirigido pelas Irmãs da Caridade o Colégio da Conceição, foi o motivo do questionamento do senador Dantas. Entretanto, disse que esta casa foi comprada, na verdade, por uma Associação de São Vicente de Paulo, composta por senhoras da sociedade da Corte e presidida pelo bispo capelão-mor, sendo, desta forma, uma associaçáo nacional, a qual pertenceria a referida casa. Respondeu ainda que o ministro dos Negócios Estrangeiros náo participava diretamente da vinda das Irmãs para a Misericórdia e para a Associação de Sáo Vicente de Paula, tendo atuado, em Paris, apenas [bondosamente] como procurador de ambas. ${ }^{43}$

O discurso do marquês de Abrantes nos permite vislumbrar um panorama político-ideológico e pensar a inserção do Império do Brasil neste debate. Dantas seria, para Abrantes, um opositor ferrenho à entrada do clero e demais religiosos estrangeiros no país, para o qual todos seriam inacianos "ou formando corporaçóes perigosas, e tendo por vanguarda as Irmás de Caridade", ${ }^{44}$ ao que Abrantes rebateu dizendo que o mesmo desconhecia a verdadeira função dos Jesuítas e dos Lazaristas na história da Igreja. Entende-se, pela fala de Abrantes, que a política imperial estaria influenciada pelas relaçóes existentes entre os vários partidos [Liberal e Conservador] mundo afora. Caso da Bélgica, por exemplo, em que diz que o Partido Conservador é denominado católico "pelo apoio que tem do clero e corporaçóes eclesiásticas". Essa relação estava lhe permitido vitórias, sobretudo no campo educacional que passaria a ter no clero a inspeção do ensino religioso nas escolas públicas, assim como também teria obtido vitórias quanto ao domínio da caridade em 1857 e, neste sentido, provocava no Partido Liberal uma enorme repulsa ao clero estrangeiro. ${ }^{45}$

No caso de Portugal, Abrantes diz que os bens eclesiásticos, ao serem tomados pelo rei D. Pedro I (1392-1449), deram um duro golpe na instituição eclesiástica, fazendo com que a mesma viesse se rearticulando no século XIX para reaver o que havia perdido. Neste sentido, o Partido Liberal português, na figura de Alexandre Herculano (1810-1877), vinha se tornando o grande opositor à entrada do clero estrangeiro no país. Para Abrantes, seria incompreensível o Partido Liberal do Império do Brasil opor-se às ordens religiosas estrangeiras, uma vez que, no Brasil, as mesmas sempre viveram [e viviam] em harmonia e às custas do Estado e, além de serem pouco numerosas, estariam organizadas apenas em algumas províncias. ${ }^{46}$

\footnotetext{
${ }^{43}$ Ibidem, p. 18.

${ }^{44}$ Ibidem, p. 19.

45 Ibidem, p. 20.

${ }^{46}$ Ibidem, p. 21 e 22.
} 
Questão religiosa e circulação de ideias: muito aquém da década de 1870 e muito além das dioceses de Pernambuco e do Pará

Diferentemente das dificuldades que Brasil e outros Estados americanos - como seria o caso do Chile, comentado por Pio IX na conversa com Uruguai - estariam enfrentando para acertar uma concordata com Roma, o governo de D. Pedro V (1837-1861), em Portugal, a fez em 21 de fevereiro de 1857. Por este documento o papa Pio IX permitia a continuidade do exercício do Real Padroado da Coroa portuguesa no Oriente, porém reduzindo-lhe o campo de influência. ${ }^{47}$ Diante deste fato nos deparamos com a reaçáo dos liberais portugueses à assinatura do acordo por meio do opúsculo "A reação ultramontana em Portugal ou a concordata de 21 de fevereiro", escrito por Alexandre Herculano. ${ }^{48}$ Lançado em maio de 1857, portanto pouco tempo depois da assinatura da concordata com Pio IX, Herculano critica a subserviência do governo português à Igreja num assunto que não caberia acordo, isto é, entendia Herculano que o governo português por toda sua história, suas lutas e glórias no Oriente tinha o direito de governar a sua Igreja.

Reagindo ao opúsculo de Herculano, D. Antonio de Almeida Portugal (1794-1874) — o marquês de Lavradio - fez "Algumas reflexôes em resposta a reação ultramontana em Portugal ou a concordata de 21 de fevereiro". ${ }^{49}$ Lavradio se posicionou ao lado da concordata e procurou rebater as teses de Herculano no tocante às críticas que fez à Companhia de Jesus, à Congregaçáo da Propaganda Fide e à superioridade do poder espiritual sobre o temporal em relaçấo ao governo das missóes portuguesas no Oriente. Pegando este "fio" em relação à extensa obra de Herculano sobre a temática Igreja e Estado, ${ }^{50}$ perguntamo-nos se seria possível algum tipo de diálogo entre o que estaria ocorrendo no Brasil com a "questão religiosa" em Portugal.

O próprio marquês de Abrantes nos dá uma pista em relação a isto. Numa tentativa de buscar explicar os motivos das críticas ao trabalho das Irmãs da Caridade junto às enfermarias da Corte, diz Abrantes que náo ousava "attribuir essa cruzada unicamente á servil imitação da que se levantou em Portugal", tendendo mais a crer que a mesma teria sido arquitetada pelo antigo administrador do Hospital da Misericórdia. ${ }^{51}$ Embora não acreditasse

\footnotetext{
${ }^{47}$ RIVARA. Joaquim Heliodoro da Cunha. A Concordata de 21 de Fevereiro de 1857 entre Sua Santidade o Papa Pio IX e sua magestado Fidelessima El-Rei de Portugal D. Pedro V; Acompanhada das notas reversaes de 10 de Setembro de 1859. Nova-Goa: Imprensa Nacional, 1860, 15 p.

${ }^{48}$ HERCULANO, Alexandre. A reação ultramontana em Portugal ou a concordata de 21 de fevereiro. Lisboa: Typ. de José Batista Morando, 1857.

${ }^{49}$ MARQUEZ de Lavradio. Algumas reflexōes em resposta a reação ultramontana em Portugal ou a concordata de 21 de fevereiro. Lisboa: Typ. De Mathias José Marques da Silva, 1859.

${ }^{50}$ MARINHO, Maria de Fátima; AMARAL, Luís Carlos; TAVARES, Pedro Vilas-Boas (Coords.). Revisitando Herculano no bicentenário do seu nascimento. Porto: Universidade do Porto, Faculdade de Letras, 2013. ${ }^{51}$ PBCM. Biblioteca do Caraça. ABRANTES [Marquês de]. As Irmâs de Caridade no Rio de Janeiro. Discurso pronunciado no Senado por S. Ex. o senhor Marquez de Abrantes na sessão de 22 de agosto, op. cit., p. 15.
} 
na primeira versão, é plausível então que houvesse uma circulação do que estaria ocorrendo em Portugal no Império, tanto que, conforme o mesmo argumentou ao responder o senador Dantas, em Portugal, o Partido Liberal estaria opondo-se ao Partido Católico, e neste sentido, criticando as ordens estrangeiras, sobretudo aos Lazaristas, como pode ser verificado no próprio opúsculo de Carlos Habeneck, Jesuitas e Lazaristas.

Um segundo exercício seria observar o aparecimento de citações e referências feitas ao próprio Alexandre Herculano em periódicos, notadamente, da capital imperial. Para que tenhamos uma ideia, em $A$ Reforma, periódico da Corte, de perfil maçom, publicado a partir de 1869 e que se notabilizava pelas ácidas críticas às investidas ultramontanas, podemos ver que Herculano era relativamente conhecido entre aqueles que escreviam, hajam vista as citaçóes e referências pontuais, aqui e acolá, de seu pensamento ou produção bibliográfica. Diferentemente do exposto em $O$ Apóstolo, periódico que se colocava ao lado das ideias religiosas ultramontanas e que em sua edição de 30 de dezembro de 1866 advertia aos fieis para que não lessem os artigos de Herculano que estavam sendo publicados no Jornal do Comércio a respeito do casamento civil. ${ }^{52}$ Quando de seu falecimento, na edição de 19 de setembro de 1877, escreveria em meio às análises de sua obra que não havia quem em Portugal e no Brasil que não o conhecesse. ${ }^{53}$

As referências a Herculano prosseguem quanto às suas exéquias, desde a recusa do clero baiano em fazê-las às críticas aos republicanos e a Ganganelli [Saldanha Marinho (1815-1895)], que reclamavam maiores homenagens e luto pela sua passagem, às exéquias encomendadas por uma comissão de portugueses eleita para tal fim no Rio de Janeiro para que ocorressem no templo de São Francisco de Paula. ${ }^{54}$ Em relação aos portugueses no Rio de Janeiro, é importante frisar que tinham espaços de sociabilidade e nos quais mantinham relaçóes com a cultura e a política portuguesa do século XIX. O Real Gabinete Português de Leitura era um desses espaços. Fundado em 14 de maio de 1837, trouxe entre seus fundadores alguns comerciantes que haviam deixado Portugal em função de perseguiçóes do absolutismo e que poderiam ter em Herculano um exemplo daquilo que almejavam expor sobre o regime político português do qual se afastaram, mas que desejavam saber notícias.

Complementa-se a esta informação o fato de o periódico Revista Catholica ter anunciado a obra "Algumas observaçôes sobre a Inquisição, sobre as crusadas e outros objetos análogos em resposta a obra intitulada - Da origem e estabelecimento da inquisição em Portugal Tentativa histórica por A. Herculano", escrita pelo marquês de Lavradio "que tanto se ha distinguido pelo seu zelo em favor da Religiáo". Alexandre Herculano seria um nome de referência na política e na cultura portuguesa do século XIX por seu destacado anticlericalismo. AFBN. Revista Catholica. Jornal do Instituto Episcopal Religioso, v. I, 15 de junho de 1856, p. 19. Disponível em: <http://memoria.bn.br/DOCREADER/DOCREADER.ASPX?BIB=738522>. Acesso em: 12 jul. 2014.

${ }^{52}$ AFBN. O Apóstolo, 30 de dezembro de 1866, p. 4, col. 4.

${ }^{53}$ AFBN. O Apóstolo, 19 de setembro de 1877, p. 1, col. 2 e p. 5, col. 3. Alexandre Herculano morreu em 14 de setembro de 1877.

${ }^{54}$ AFBN. O Apóstolo, 10 de outubro de 1877, p. 3, col. 4. 
Segundo Fabiano Azevedo, a literatura teve papel importante na formação do Real Gabinete, o que pode ser observado pelo acervo de 1844, em que constava em segundo lugar na relação de assuntos mais representativos. Além de atender aos portugueses, a biblioteca do Real Gabinete também seria aberta a brasileiros, o que, entendemos, permitiria um contato maior com a obra e as ideias do autor em questão. ${ }^{55}$ Consultando o acervo do Real Gabinete e seus respectivos catálogos de livros, que no século XIX datam de 1840, 1844, 1846, 1858, 1868 e, por fim, o catálogo de 1895, organizado por Ramiz Galvão (1846-1938), foi possível identificar 88 registros de publicações de autoria de Alexandre Herculano, editadas entre os anos de 1836 e 1900.

Quantidade bem maior que os 38 exemplares presentes no acervo da Biblioteca Nacional do Rio de Janeiro, cujas datas de publicação variam entre 1848-1895. Afora isto, temos ainda, no acervo das duas instituiçóes, 57 publicações feitas por comentadores de Herculano ou por ele mesmo em coautoria. Seria o Real Gabinete um locus pelo qual os escritos de Alexandre Herculano chegariam ao Brasil, além, é claro, das pontuais publicaçóes que poderiam ser realizadas no Jornal do Comércio ou em outros periódicos da Corte? Entendemos que sim, afora as bibliotecas particulares que também existiam no Rio de Janeiro e que contavam com uma diversidade de autores influenciados pelas ideias iluministas e liberais da passagem do século XVIII ao XIX, como nos é apresentado por Tânia Bessone Ferreira. ${ }^{56}$

Este seria o caso da própria biblioteca de Nabuco de Araújo, também repleta de publicações do direito civil francês e da legislação portuguesa entre 1750 e 1820, além de um grande número de jornais de diversas províncias do império, identificando-se algumas poucas referências a autores, como seriam os casos de Jeremy Bentam e Blaise Pascal. ${ }^{57}$ Quanto a Alexandre Herculano, identifica-se que era referência entre os autores lidos por Nabuco de Araújo, como fala Teixeira de Freitas (1816-1883) ao opinar sobre o projeto de casamento civil de Nabuco, muito embora o jurista fosse resistente àquela proposta de lei dado seu catolicismo expresso. ${ }^{58}$

De todo modo, é preciso levar em consideração a própria historiografia portuguesa sobre o tema. A partir dela podemos identificar que existiam outros textos e livros que, se não eram idênticos, abordavam temáticas muito parecidas com o que circulará no Brasil e que

\footnotetext{
${ }^{55}$ AZEVEDO, Fabiano Cataldo de. Contributo para o perfil do público leitor do Real Gabinete Português de Leitura (1837-1847). Cultura: revista de história e teoria das ideias, v. 28, 2011. Disponível em: <http:// cultura.revues.org/189\#quotation>. Acesso em: 21 fev. 2015.

${ }^{56}$ FERREIRA, Tânia Maria Bessone. Palácios de destinos cruzados: bibliotecas, homens e livros (1870-1920). Rio de Janeiro: Arquivo Nacional, 1999.

${ }^{57}$ IHGB. Inventários de livros, jornais e mobília existentes no escritório do Cons ${ }^{\circ}$ Nabuco de Araújo (Anos de 1862,63 e 66).

${ }^{58}$ NABUCO, Joaquim. Um estadista do império. Nabuco de Araújo. Sua vida, suas opiniôes, sua época. Tomo I (1813-1857). Rio de Janeiro: H. Garnier, Livreiro-Editor p. 379. CERQUEIRA FILHO, Gisálio. Augusto Teixeira de Freitas por Joaquim Nabuco: ultramontanismo versus catolicismo ilustrado. In: NEDER, Gizlene; CERQUEIRA FILHO, Gisálio. Ideias jurídicas e autoridade na família. Rio de Janeiro: Revan, 2007, p. 83-94.
} 
trará ao campo político toda a efervescência do debate em torno das ideias políticas laicizadoras daquele tempo. A título de exemplo teríamos aqui O Papa Rei e o Concílio escrito por Manuel Nunes Giraldes, e editado em 1870, pelo qual se procurava sintetizar a crítica liberal ao dogma da infalibilidade papal saída do Concílio Vaticano I (1869-1870), tal qual Johann Joseph Ignaz Von Döllinger (1799-1890) também o havia feito na Alemanha em O papa e o Concílio e teria sua obra traduzida no Brasil por Rui Barbosa (1849-1922), em 1877.59

Diante desta historiografia, é preciso atentar para o dimensionamento do que em Portugal é conhecido como "questão religiosa". Trata-se aqui de entender um processo de reforma imposta pelo Estado lusitano à Igreja e que varia com maior ou menor intensidade ao longo do século XIX. Sua primeira etapa pode ser entendida a partir das reformas iniciadas entre as décadas de 1820 a 1830, que culminou com a vitória dos liberais na guerra civil de 1834. Terminado o conflito, os liberais aboliram os dízimos, ordens religiosas masculinas foram extintas e expropriadas, a profissão de frade foi proibida e novos noviciados também foram extintos, sendo mais uma vez os jesuítas expulsos do reino. As ordens religiosas femininas foram mantidas desde que tivessem ao menos doze membros, e os membros do clero regular foram convidados a compor o clero secular, pois a religião ainda era vista pelos liberais com grande influência na moral da sociedade. ${ }^{60}$

Nesta época, o movimento laicista português estaria absorvendo um ideal antijesuítico, anticongregacionista e anticlerical, que faria parte da legislação portuguesa com a instauração da República no início do século XX. Diz Fernando Catroga que os lacistas buscavam denunciar os malefícios que o clero, sobretudo o regular, provocava na sociedade "enquanto agente educativo, assistencial ou religioso". ${ }^{61}$ Tal como no Brasil, esse movimento atacaria a ação das Irmãs da Caridade e aos Lazaristas, uma vez que às vistas dos laicistas nada mais eram do que instituiçóes estrangeiras que fugiam ao controle da Igreja nacional, portanto ao ideal construído por Pombal ainda no século XVIII.

Assim sendo, no plano das discussóes laicistas que emergiriam em Portugal no século XIX, Catroga chama a atenção para contribuição que alguns escritos que questionavam o celibato eclesiástico dariam a esta discussão, sendo que um dos primeiros textos a circular no reino teria sido editado em primeira mão no Brasil, em 1828, de autoria do padre Luiz Gonçalves dos Santos, ${ }^{62}$ e reeditado em Portugal dois anos mais tarde. ${ }^{63}$ Catroga continua

\footnotetext{
${ }^{99}$ CATROGA, Fernando. O laicismo e a questão religiosa em Portugal (1865-1911). Análise Social, Lisboa, n. XXIV (1.o), n. 100, p. 226, 1988. Disponível em: <http://analisesocial.ics.ul.pt/?page_id=12>. Acesso em: 23 jun. 2014.

${ }^{60}$ LEAL, Manuel M. Cardoso. A Questão Religiosa em José Luciano de Castro: a lógica do Estado liberal nas relações com a Igreja. Lusitania Sacra, Lisboa, t. 26, p. 104-105, julho-dezembro, 2012.

${ }^{61}$ CATROGA, Fernando. O laicismo e a questão religiosa em Portugal (1865-1911), op. cit., p. 211-273. p. 211. ${ }^{62}$ SANTOS, Luís Gonçalves dos. Memórias para servir à História do Brasil. São Paulo: EdUSP/Belo Horizonte: Itatiaia, 1981, v. 1, p. 20

${ }^{63}$ A referência a seguir é a reeditada em Lisboa, em 1830. SANTOS, Luiz Gonçalves dos. A voz da verdade da Santa Igreja Catholica, confundindo a voz da mentira do amante da humanidade, para sedativo da effervescencia casamenteira dos modernos anti-celibatarios. Lisboa: Typographia de Bulhóes, 1830.
} 
a nos oferecer alguns elementos que entendemos ser importantes para pensar esta [possível] circulação de ideias entre Brasil e Portugal quanto à questão religiosa. Destaque-se aqui, além da própria circulação de escritos contrários às ordens religiosas estrangeiras como seria o caso dos Lazaristas e das Irmãs da Caridade, a emergência de uma literatura que buscava pensar os interesses da Igreja no controle da família portuguesa, a exemplo da questão da confissão auricular, como seria o caso de Eça de Queiroz em $O$ crime do padre Amaro. Muito embora, para o movimento laicista português não bastaria apenas pôr fim à confissão auricular posto que a campanha deveria ter uma profundidade muito maior, pois haveria necessidade de incidir

[...] na libertação da família da intromissão clerical, o que [...] comumente acontecia através das confidências feitas durante a confissão. Daí que esta surgisse, a par do controlo dos estabelecimentos de ensino e dos actos essenciais da existência (nascimento, casamento e morte), como o maior instrumento de poder que a Igreja detinha. ${ }^{64}$

Do mesmo modo, dada a atração feminina pelo confessionário, seria pertinente também o combate ao celibato eclesiástico, o que aprofundaria o debate iniciado por Sampaio Bruno que, até então, havia se limitado à lembrança do texto do padre Luiz Gonçalves dos Santos. Neste sentido, o movimento laicista recupera um debate que já havia ocorrido durante o período do vintismo e o setembrismo português.

Se nos lembrarmos da punição recebida pelo reverendo padre José Luiz de Almeida Martins imposta pelo bispo do Rio de Janeiro, veremos como ela se volta justamente para isto que nos fala a historiografia portuguesa. José Luiz foi suspenso de confessar e de pregar. Portanto, o confessionário e o púlpito eram vistos como lócus tanto para os laicistas quanto para os ultramontanos capazes de mapear e influenciar a sociedade em formação. Assim também, a sociedade poderia ser influenciada a partir das escolas, pois desde a mais tenra infância laicistas e ultramontanos estariam procurando moldar a criança neste plano.

\section{Conclusão}

As constantes críticas à atuação dos Lazaristas nos dois lados do Atlântico não podem ser pensadas sem nenhuma ligação, tampouco a própria referência a estes religiosos não pode ser pensada sem que se leve em consideração a trajetória da Ordem ao longo da história da Igreja e das ideais religiosas. Neste sentido, entendemos que coube à Congregação da Missão ocupar um lugar, sobretudo no campo educacional, deixado vago após a extinção da Companhia de Jesus em 1773.

${ }^{64}$ CATROGA, Fernando. O laicismo e a questão religiosa em Portugal (1865-1911), op. cit., p. 219. 
Em um momento de limitação à entrada do clero estrangeiro no Brasil e necessitando de ordem religiosa com experiência junto ao trabalho com os pobres e com as escolas, os Lazaristas foram gradativamente se organizando e constituindo-se no instituto religioso mais organizado no Segundo Reinado.

Tal atuação estaria relacionada a trabalhar um perfil de sociedade comprometida com ultramontanismo, portanto intencionada a uma mudança cultural no plano da vivência da fé católica no Brasil. Diante do avanço ultramontano, o campo político imperial se vê às voltas com a necessidade de se estabelecer um controle maior em relação à entrada das ordens estrangeiras. Seria preciso trabalhar com aquelas que se submetessem ao poder temporal e seu projeto de secularização das instituiçôes. A família, por exemplo, precisava de se formar civilmente, pois as demandas do mercado de trabalho implicavam a vinda de imigrantes de países não católicos europeus, quando não orientais.

Atuando nas frentes ultramontanas, sejam elas de sotaina ou de casava, os ultramontanos intervinham no campo político com o intuito de barrar as reformas. Daí o ataque à maçonaria presente nos mais diferentes estratos sociais do século XIX e, principalmente, nas fileiras do legislativo e do Conselho de Estado imperial.

$\mathrm{O}$ ataque ao padre José Luiz de Almeida Martins seria, na verdade, uma forma de atingir ao visconde do Rio Branco. E tempos depois a ação dos bispos em desobedecer ao beneplácito imperial estender-se-ia a outras dioceses. O fato é que a historiografia brasileira limitou a noçấo de "questão religiosa" à década de 1870, mas a análise da documentação feita neste artigo nos levou a repensar este conceito.

\section{Referências bibliográficas}

ABRANTES [Marquês de]. As Irmãs de Caridade no Rio de Janeiro. Discurso pronunciado no Senado por S. Ex. o senhor Marquez de Abrantes na sessão de 22 de agosto. Rio de Janeiro: Typographia de F. de Paula Brito, 1859.

ALMEIDA, Cândido Mendes de. Discurso pronunciado na sessão de 20 de julho de 1869 sobre as ordens religiosas. O Apóstolo. 22 de agosto de 1869.

AZEVEDO, Fabiano Cataldo de. Contributo para o perfil do público leitor do Real Gabinete Português de Leitura (1837-1847). Cultura: revista de história e teoria das ideias, v. 28, 2011.

FERREIRA, Tânia Maria Bessone. Palácios de destinos cruzados: bibliotecas, homens e livros (1870-1920). Rio de Janeiro: Arquivo Nacional, 1999.

CATROGA, Fernando. O laicismo e a questão religiosa em Portugal (1865-1911). Análise Social, Lisboa, v. XXIV, n. 100, (1. $\left.{ }^{\circ}\right), 1988$. 
CERQUEIRA FILHO, Gisálio. Augusto Teixeira de Freitas por Joaquim Nabuco: ultramontanismo versus catolicismo ilustrado. In: NEDER, Gizlene; CERQUEIRA FILHO, Gisálio. Ideias jurídicas e autoridade na família. Rio de Janeiro: Revan, 2007.

ENNES, Antonio. O conservatório dramático do Rio de Janeiro e o drama Os Lazaristas. Carta ao Sr. Conselheiro Cardoso de Menezes. Lisboa: Typographia do Jornal — O Paiz. Rua do Alecrim, 89, 1875.

ENNES, Antonio. Os Lazaristas. Drama original em tres actos. Rio de Janeiro: Imprensa Industrial, s/d.

HABENECK, Carlos. Jesuitas e Lazaristas. Segunda edição aumentada de Os jesuitas em 1860. Lisboa: Typ. de J. G de Souza Neves, Rua do Caldeira, 1862.

HERCULANO, Alexandre. A reação ultramontana em Portugal ou a concordata de 21 de fevereiro. Lisboa: Typ. de José Batista Morando, 1857.

LEAL, Manuel M. Cardoso. A questão religiosa em José Luciano de Castro: a lógica do Estado liberal nas relaçôes com a Igreja. Lusitania Sacra, Lisboa, t. 26, julho-dezembro, p. 103-132, 2012.

MARINHO, Maria de Fátima; AMARAL, Luís Carlos; TAVARES, Pedro Vilas-Boas (Coords). Revisitando Herculano no bicentenário do seu nascimento. Porto: Universidade do Porto, Faculdade de Letras, 2013.

MARQUEZ de Lavradio. Algumas reflexóes em resposta a reação ultramontana em Portugal ou a concordata de 21 de fevereiro. Lisboa: Typ. De Mathias José Marques da Silva, 1859.

MICELI, Sergio. A elite eclesiástica brasileira. Rio de Janeiro: Bertrand Brasil, 1988.

NABUCO, Joaquim. Um estadista do Império. Nabuco de Araújo. Sua vida, suas opiniōes, sua época. Tomo I (1813-1857). Rio de Janeiro: H. Garnier, Livreiro-Editor.

OLIVEIRA, Anderson José Machado de. Os bispos e os leigos: a reforma católica e as irmandades no Rio de Janeiro. Revista de História Regional, Ponta Grossa, v. 6, n. 1, p. 147160, 2001.

Revista Catholica. Jornal do Instituto Episcopal Religioso, v. I, 15 de junho de 1856.

RIVARA. Joaquim Heliodoro da Cunha. A Concordata de 21 de Fevereiro de 1857 entre Sua Santidade o Papa Pio IX e sua magestado Fidelessima El-Rei de Portugal D. Pedro V; Acompanhada das notas reversaes de 10 de Setembro de 1859. Nova-Goa: Imprensa Nacional, 1860.

SANTIROCCHI, Ítalo Domingos. Dois poderes em desacordo: o fracasso da Concordata de 1858. Anais da Associaçâo Brasileira de História das Religióes. Religião, carisma e poder: As formas da vida religiosa no Brasil — 29/05 a 01/06/2012. São Luís, v. 13, s/p., 2012. SANTOS, Luís Gonçalves dos. Memórias para servir à História do Brasil. São Paulo: EDUSP/ Belo Horizonte: Itatiaia, 1981. 
SANTOS, Luiz Gonçalves dos. A voz da verdade da Santa Igreja Catholica, confundindo a voz da mentira do amante da humanidade, para sedativo da effervescencia casamenteira dos modernos anti-celibatarios. Lisboa: Typographia de Bulhōes, 1830.

SCHUBERT, Guilherme. A provincia eclesiástica do Rio de Janeiro. Rio de Janeiro/Belo Horizonte: Agir Editora, 1948.

TEIXEIRA, Duque Estrada. Questâo religiosa interpellaçâo do deputado Duque Estrada Teixeira sessão de 6 de julho de 1874 Debate entre o mesmo deputado o o Ministro do Imperio. Rio de Janeiro: Typ. Imperial e Constitucional de J. Villeneuve E C., 1874.

TÔRRES, João Camilo de Oliveira. História das ideias religiosas no Brasil. A Igreja e a sociedade brasileira. São Paulo: Editorial Grijalbo Ltda, 1968.

VIEIRA, David Gueiros. O protestantismo, a maçonaria e a questão religiosa no Brasil. 2. ed. Brasília: EdUnB, s/d.

VILLAÇA, Antonio Carlos. História da questão religiosa no Brasil. Rio de Janeiro: Francisco Alves, 1974.

ZICO, José Tobias. Caraça: peregrinação, cultura e turismo (1770-1976). 5. ed. Contagem, MG: Editora Littera Maciel, 1988. 